\title{
УДК $621.315 .2: 004.94$ \\ COUPLED ELECTRICAL AND MECHANICAL PROCESSES IN POLYETHYLENE INSULATION WITH WATER TREE HAVING BRANCHES OF COMPLEX STRUCTURE
}

\author{
I.M.Kucheriava \\ Institute of Electrodynamics National Academy of Sciences of Ukraine, \\ pr. Peremohy, 56, Kyiv-57, 03680, Ukraine. E-mail: rb.irinan@gmail.com
}

The distributions of electric field, electric force and mechanical stress in the polyethylene insulation of power cable that contains separate branch of a water tree are studied by computer modeling. Two models of water tree branch which include a string of water-filled spherical microcavities connected by cylindrical channels with equal radius and with radius decreasing along the length of the branch are examined. It is shown that the action of electric force and electromechanical stresses at the ends of thinner tree channels can cause their destruction and then growth of water trees in polyethylene insulation. References 15 , figures 5 , table 1.

Key words: polyethylene insulation, micro-sized water-filled cavities and channels, electric field, mechanical stress, computer modeling.

Introduction. At present the high- and extra-high voltage cables with cross-linked polyethylene insulation (up to $500 \mathrm{kV}$ ) are widely used in the world. The polyethylene (PE) insulation possesses superior electrical and mechanical properties, thermal stability. This gives high reliability of the material under operating conditions. At the same time, the microlevel structure of polyethylene insulation is heterogeneous due to the presence of numerous cavities, voids, cracks, foreign inclusions and various imperfections. Under the influence of electric field and in moist or aqueous medium, the voids and cavities over time fill up with water or water vapor. They become similar to tree with branches and channels. In that way the initiation and growth of water trees take place [13]. Water trees are tree-like structures with branches that through electrophoresis and mechanical effects grow and develop in polyethylene material. In such circumstances water is aggregated in high electric field regions by dielectrophoresis and expands in the microcavities and microcracks in polyethylene. In order to grow water trees need water and electric field.

Because of degradation of the insulated material, water trees lead to its deterioration in service, reduction of electric strength and shortening of cable service life [4]. The main question is whether or not water trees can cause quick failure of power cables. That is why the phenomenon of water treeing is studied extensively, e.g. in [1, 11-13].

The typical water treeing as a set of branched water-filled channels in polyethylene insulation [12] and its structure in conventional form are shown in fig. 1, $a$ and fig. 1, $b$, respectively.

The initiation and growth mechanisms of water trees in polyethylene insulation are not clearly understood. The mechanisms are complex interactions of the electrical, mechanical and chemical processes depending on state and properties of the material, external conditions, applied stresses. The mechanisms of be-

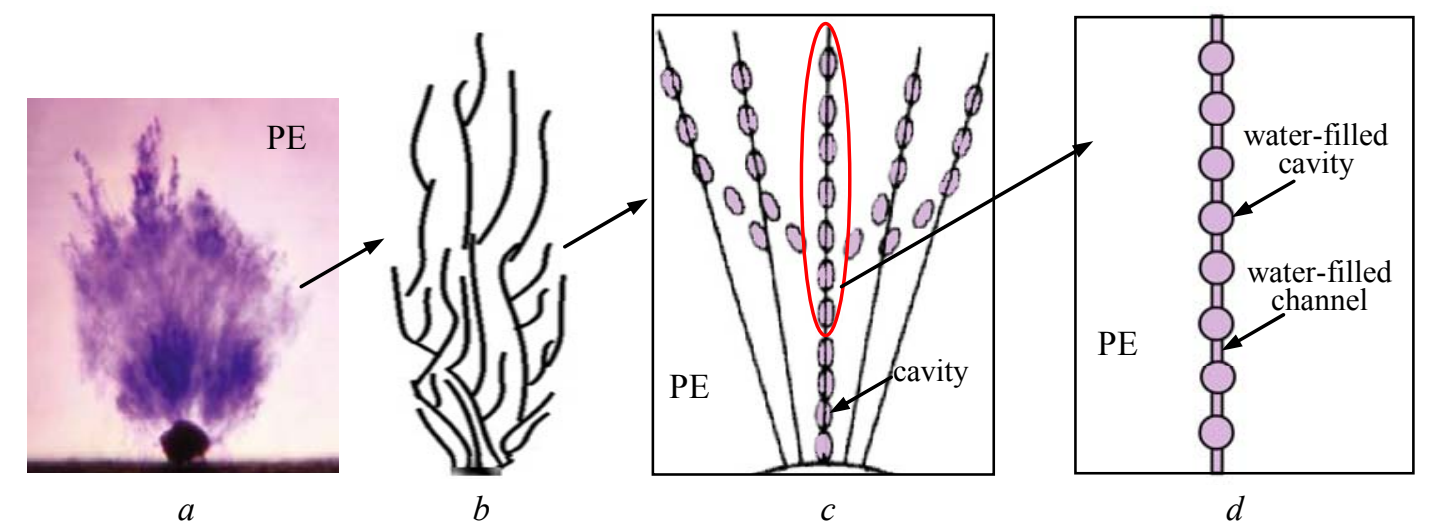

Fig. 1

(C) Kucheriava I.M., 2016 
ginning and further growth of water trees are subdivided into two basic categories such as electromechanical and electrochemical mechanisms $[8,12,14]$. One of the main reasons to form water trees are mechanical stresses that result from the action of electric force in dielectrics.

The destructive effect of electromechanical phenomena occurs as follows [3, 4, 15]. The nonuniform distribution of electric field in heterogeneous polyethylene insulation in conjunction with distortion of the field near the defects in the insulation generate mechanical forces. The forces cause stresses which are the most intensive in the vicinity of the defects where the electric field is sharply non-uniform. The mechanical stresses bring to the destruction and break of chemical bonds in polymer matrix, formation of more vast cavities and propagation of water trees. Then the concentration of electric field and mechanical stresses at the tips of water tree leads to its more accelerated growth.

The models of treeing growth from microcavities according to $[1,14]$ are presented in fig. $1, c, d$. They are based on the concept that water tree has a "trunk" structure. Each branch in the tree contains a chain of water microcavities connected by water-filled microchannels (fig. 1, $d$ ). In compliance with [14] the initial water microcavities in polyethylene arise from manufacture process and operation owing to amorphous region containing water, coagulation of submicrovoids and submicrocavities and by grouping of free volume in polyethylene structure. Water trees tend to grow along the electric field lines by means of the spread of microcavities and voids.

The model of water tree shown in fig. $1, c$ is described in articles $[8,14]$. It is in keeping with experimentally corroborated idea that water trees consist of a collection of spherical microcavities filled with water [14]. The similar model of water tree branch structured by the water-filled spherical microcavities and cylindrical channels (fig. 1, $d$ ) is used in [1]. Just such a model for the branch of water tree is examined in the present article under condition of circular channels of the same diameter (model 1 in fig. 2,a) and in the case of narrowing of water-filled channels (model 2 in fig. $3, a$ ).

The mechanisms of degradation of polyethylene insulation including the increase of electric intensity in close proximity to voids, cavities and tips of branch-like treeing, the action of electric force, attracting the water molecules towards the regions with more strong field, are studied by computer modeling in [11].

No complete explanation for the possible aging and failure mechanisms of cable insulation associated with force effects and mechanical stresses in non-uniform electric field is yet available. The detailed study of these mechanisms gives a possibility to define the causes and take the measures to prevent the polyethylene degradation and eventually to attain the high quality of cable insulation along with its prolonged service life. That affirms the topicality of investigation of electrophysical processes in heterogeneous dielectrics, especially as applied to polyethylene insulated power cables.

The purpose of the present work is to study features of the distributions of electric field, electric force and electromechanical stress in the polyethylene insulation having water tree branch that contains a chain of water micro-sized cavities connected by water-filled microchannels of different thickness.

Statement of physics problems. Let us consider the region of polyethylene insulation having a water tree branch under the action of alternating electric field changing harmonically with defined angular frequency $\omega$. The model of the branch includes a sequence of spherical microcavities connected by cylindrical channels of different thickness (fig. 2,a). The cavities and the channels are filled with water.

The problems are formulated as two-dimensional, axisymmetric problems in cylindrical coordinates $r O z$ (fig. 2,a).

The electric field problem is stated in quasi-static approximation. This implies that the field slowly changes in time at preset frequency $f=50 \mathrm{~Hz}$.

The problem of structural mechanics is solved only in polyethylene insulation except for water tree branch. The assumption concerning the lack of the external loads, residual stresses and initial pressure is made. The stresses that arise from electric forces are taken into consideration.

The insulation material is assumed to be isotropic.

Electric field problem. The distribution of electric field $\dot{\mathbf{E}}=-\nabla \dot{\varphi}$ is determined from the following equation solved for complex electric potential $\dot{\varphi}$ :

$$
\nabla \cdot\left[\left(\sigma \nabla \dot{\varphi}+j \omega \varepsilon_{0} \dot{\varepsilon}_{r} \nabla \dot{\varphi}\right]=0,\right.
$$

where $\sigma$ is the conductivity of the material; $\dot{\varepsilon}_{r}$ is the complex relative permittivity; $\varepsilon_{0}=8,85 \cdot 10^{-12} \mathrm{~F} / \mathrm{m}$ is the vacuum permittivity; $j$ is the imaginary unit; $\omega=2 \pi f$ is the angular frequency. 
Model 1 of water tree branch

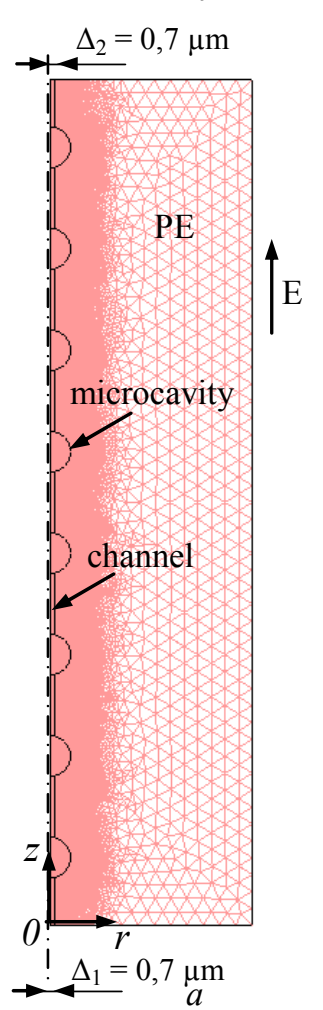

Model 2 of water tree branch

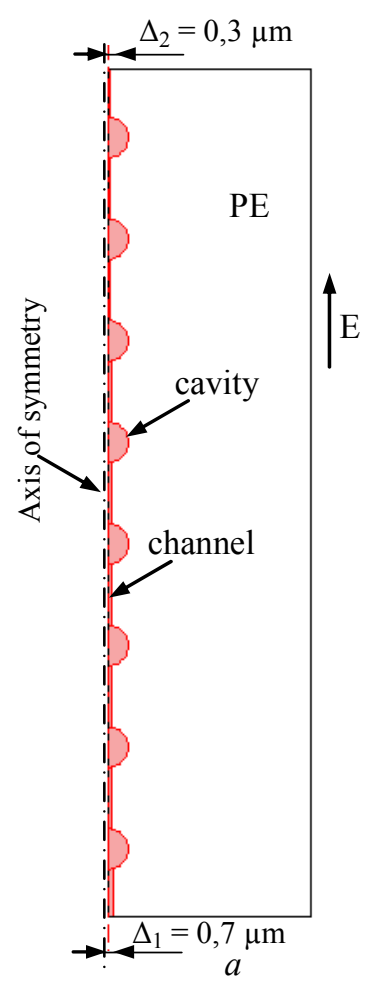

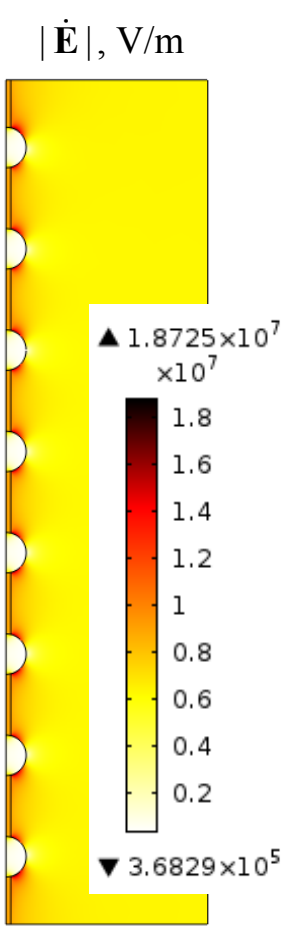

$b$
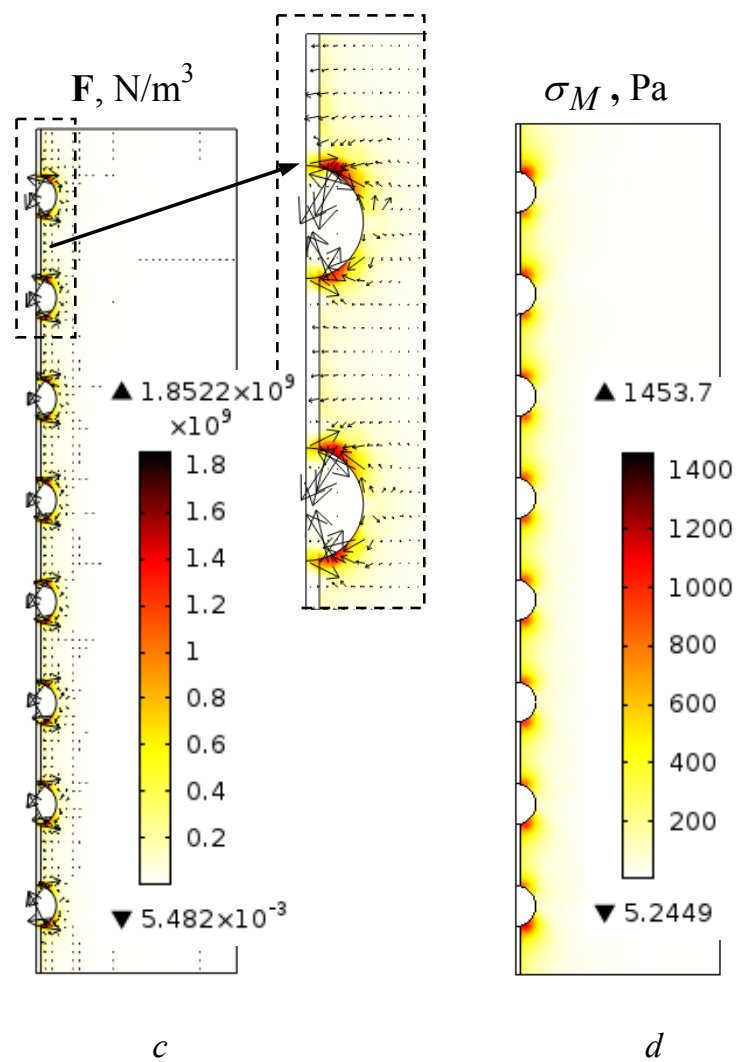

Fig. 2
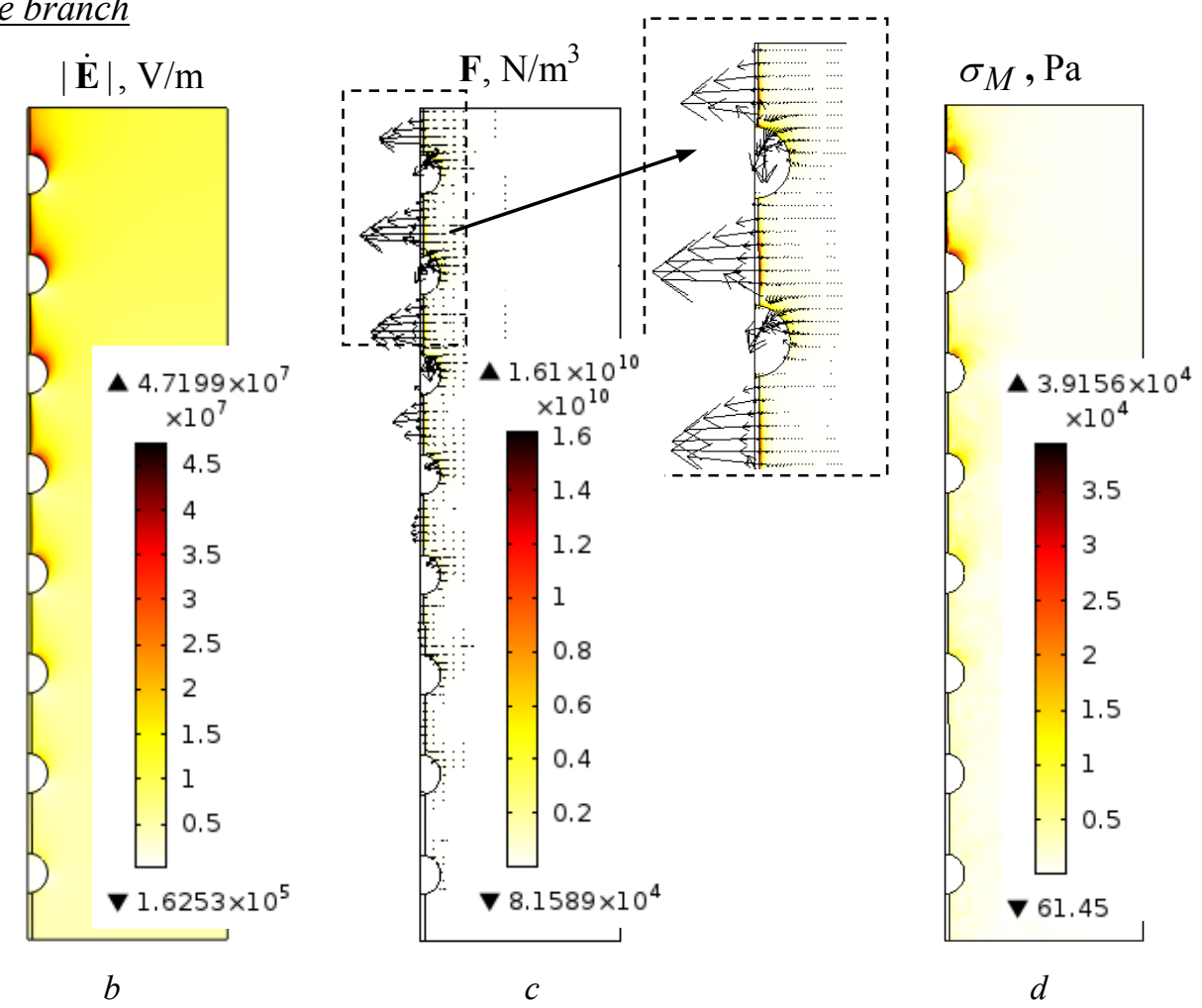

Fig. 3

The next boundary conditions are specified. The conditions $\dot{\varphi}=0$ and $\dot{\varphi}=U$ (where $U$ is the phase voltage) are assigned on the boundaries along the field. The axial symmetry is defined at $r=0$. The condition of electric insulation such as $\mathbf{n} \cdot \mathbf{J}=0$ ( $\mathbf{n}$ is the unit external normal; $\mathbf{J}$ is the total current density) is set on the outer boundary.

Structural mechanics problem. The electromechanical stresses within polyethylene material are computed by the equation: 


$$
\nabla \sigma_{m}+\mathbf{F}=0 .
$$

Here $\sigma_{m}$ is the stress tensor; $\mathbf{F}$ is the electric force per unit volume (average value in a time period) that acts on dielectric. Making an assumption that there are no space charges in the dielectric medium, the force is expressed as [7]: $\quad \mathbf{F}=\frac{\varepsilon_{0}}{2} \nabla(\varepsilon-1)|\dot{\mathbf{E}}|^{2}$.

The free constraint conditions are specified on all boundaries of computational region of the problem when no external force is applied.

The detailed description of the quantities needed to determine the stress tensor $\sigma_{M}$ is given in monograph [9].

Coupling of the problems and their solving. According to the classification of coupled field problems in [5], the electric field problem (1) and structural mechanics problem (2) are weakly coupled problems. They form electromechanical multiphysics problem. The coupling between the electric field and stresses is conditioned by availability of force $\mathbf{F}$ in the equation of mechanical equilibrium (2). In compliance with expression (3), the force $\mathbf{F}$ is determined by electric field $\dot{\mathbf{E}}$ computed after solving the differential equation (1).

The problems are solved using the finite-element software Comsol Multiphysics [2]. The fine mesh of the computational regions (shown in figs. 2,a and 3,a) especially close to the microcavities and channels is used. The mesh is illustrated in fig. 2, $a$.

Note that the similar electric and mechanical problems coupled with thermal problem are solved in article [10] in a three-dimensional domain with different branched treeing structures. The accuracy of computational results is verified in [10] by comparison of computed values of electric force $\mathbf{F}$ with experimental data.

Numerical results and discussion. The properties of components and parameters of computational model are listed in table. In the developed model, the relative dielectric permittivity of water tree is set to be

\begin{tabular}{|l|c|}
\hline \multicolumn{1}{|c|}{ Parameters and quantities } & Values \\
\hline Geometric parameters & \\
\hline Radius of microcavities in polyethylene, $\mu \mathrm{m}$ & 3 \\
\hline Half-thickness of water-filled channels, $\Delta, \mu \mathrm{m}$ & from 0,3 to 0,7 \\
\hline Dimensions of computational region, $\mu \mathrm{m}$ & $30 \times 125$ \\
\hline Electrical quantities \\
\hline Average electric field in insulation, $\mathrm{kV} / \mathrm{mm}$ & 7 \\
\hline Frequency, $\mathrm{Hz}$ & 50 \\
\hline Conductivity of polyethylene insulation, $\mathrm{S} / \mathrm{m}$ & $10^{-15}$ \\
\hline Conductivity of cavities and channels, $\mathrm{S} / \mathrm{m}$ & $5 \cdot 10^{-2}$ \\
\hline Relative dielectric permittivity of polyethylene & 2,3 \\
\hline Relative permittivity of medium in water tree & 5 \\
\hline Mechanical quantities of polyethylene & 700 \\
\hline Young's modulus, MPa & 0,46 \\
\hline Poisson's ratio & 930 \\
\hline Density, $\mathrm{kg} / \mathrm{m}^{3}$ &
\end{tabular}

5 in accordance with measurements in [6].

The computer modeling is carried out for two models, namely for model 1 of water tree branch with water-filled channels having the same thickness $\Delta_{1}=\Delta_{2}=0,7$ $\mu \mathrm{m}$ (fig. 2,a) and for model 2 when the thickness of the channels is varied from $\Delta_{1}=0,7 \mu \mathrm{m}$ to $\Delta_{2}=0,3 \mu \mathrm{m}$ (fig. $3, a$ ).

The computed distributions of electric intensity $|\dot{\mathbf{E}}|$, electric force $\mathbf{F}$ and von Mises stress $\sigma_{M}$ are shown in figs. 2 and 3, $(b-d)$ for two models under examination. In addition, fig. 4 presents for model 1 of water tree branch the variation of electric intensity (fig. 4, $a$ ), electric force (fig. 4, $b$ ) and von Mises stress (fig. $4, c$ ) along the boundary of water-filled channels $(r=0,7 \mu \mathrm{m})$. As seen, the concentration and the maximum values of these quantities take place in close proximity to the boundary of microcavities with channels and near the tops of the cavities directed along the field. The electric intensity inside the microcavities is low. The greatest electric force $|\mathbf{F}|$ acts on the cavities. The force has a compressive effect on both the cavities and water-filled channels. In consequence of the compression force, the local deformation and destruction of polyethylene insulation at microlevel, in particular in the region of transition from cavities to channels can be started.

For model 2 of water tree branch, fig. 5 gives the change of electric intensity $|\dot{\mathbf{E}}|$ (fig. 5,a) and force $|\mathbf{F}|$ (fig. 5, $b$ ) along the boundary of connecting channels (i.e. along the vertical line on the level of $r=$ $\left.\Delta_{1}=0,7 \mu \mathrm{m}\right)$. Together with fig. $3,(b-d)$ data of fig. 5 show the increase of the quantities under study at narrowing of the channels. If the radius of water-filled channel is reduced $\sim 2,3$ times, then the values of force $|\mathbf{F}|$ increase more than 8 times and the von Mises stress $\sigma_{M}$ increases up to 27 times (fig. 3). For nar- 

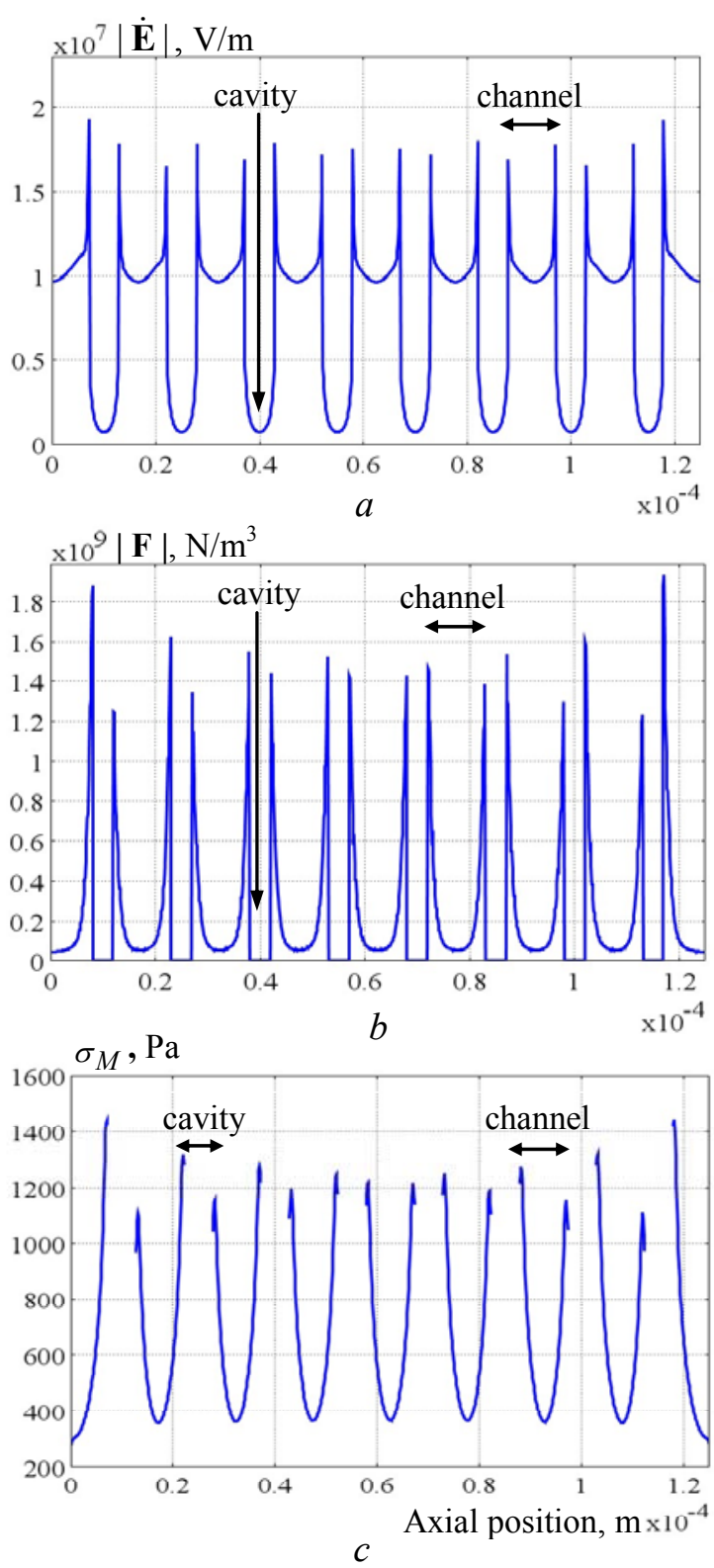

Fig. 4
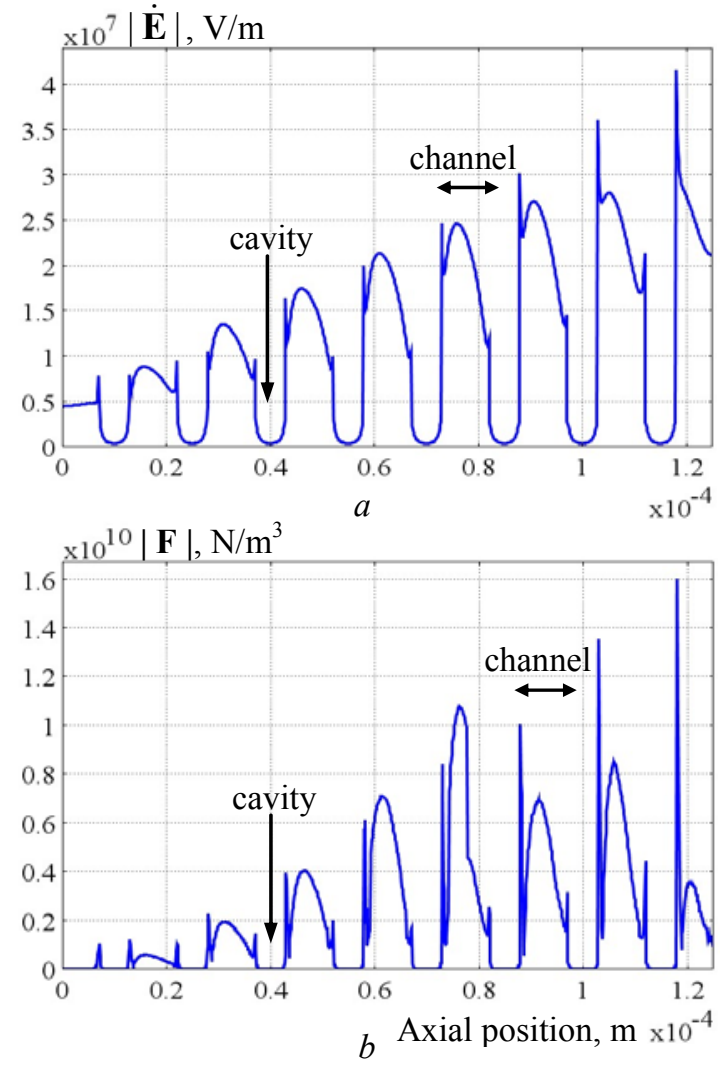

Fig. 5

rower water-filled channel the greater electric force acts in the vicinity and the higher compressive effect on the channel takes place. That creates the conditions and explains the growth of water trees at the ends of their branches, particularly under conditions of cyclic mechanical loads.

The numerical results presented in this article are in agreement with the theoretical concepts and experimental data of works $[4,13,15]$.

Conclusion. The computer modeling of the coupled electric processes and stresses in polyethylene insulation with a separate branch of water tree that con-

tains a chain of microcavities (with radius of $3 \mu \mathrm{m}$ ) and cylindrical connecting channels with different radius (from 0,3 to $0,7 \mu \mathrm{m}$ ) is performed.

The revealed electromechanical effects explain the potential mechanism of water tree propagation in cable insulation by polyethylene destruction owing to the compression force and mechanical fatigue of the material at the ends of water-filled microchanels that form branched tree structure.

The action of electric force and the effect of stresses on polyethylene insulation show that the tree branch tends to grow and the thinner branch has a higher probability of destruction.

The results attained by numerical simulation give a possibility to extend the understanding of the electrophysical processes that cause degradation of polyethylene insulation under the action of electric field. The results are of practical interest in view of wide application of polyethylene-insulated power cables.

1. Boggs S.A. Mechanisms for degradation of TR-XLPE impulse strength during service aging // IEEE Trans. on Power Delivery. - 2002. - Vol. 17. - No 2. - Pp. 308-312. Available at: http://faculty.ims.uconn.edu/ eprcable /ref06.pdf (accessed 15 February 2016).

2. Comsol multiphysics modeling and simulation software. Available at: http://www.comsol.com/ (accessed 15.02.16).

3. Crine J.P., Jinder J. A water treeing model // IEEE Trans. on Dielectrics and Electrical Insulation. - 2005. Vol. 12 (4). - Pp. 801-808.

4. Dissado L.A., Fothergill J.C. Electrical degradation and breakdown in polymers. - London: Peter Peregrinus Ltd. for IEE, 1992. $-601 \mathrm{p}$. 
5. Hameyer K., Driesen J., De Gersem H., Belmans R. The classification of coupled field problems // IEEE Trans. on Magnetics. - 1999. - Vol. 35. - No 3. - Pp. 1618-1621.

6. Koo J.Y., Cross J.D., El-Kahel M., Meyer C.T., Filippini J.C. Electrical behavior and structure of water trees in relation to their propagation // Proc. of the IEEE Conference on Electrical Insulation and Dielectric Phenomena. 1983. - Pp. 301-305.

7. Landau L.D., Livshits E.M. Electrodynamics of continuous media. - Moskva: Nauka, 1982. - 621 p. (Rus)

8. Nunes S.L., Shaw M.T. Water treeing in polyethylene - a review of mechanisms // IEEE Trans. on Electrical Insulation. - 1980. - Vol. EI-15. - No 6. - Pp. 437-450.

9. Podoltsev A.D., Kucheriava I.M. Multiphysics modeling in electrical engineering. - Kyiv: Institute of Electrodynamics of National Academy of Sciences, 2015. - 305 p. (Rus)

10. Podoltsev A.D., Kucheriava I.M. Multiphysics processes in the region of inclusion in polyethylene insulation of power cable (three-dimensional modeling and experiment) // Tekhnichna Elektrodynamika. - 2015. - No 3. Pp. 3-9. (Rus)

11. Shidlovskij A.K., Shcherba A.A., Zolotarev V.M., Podoltsev O.D., Kucheriava I.M. Extra-high voltage polymeric insulated cables. - Kyiv: Institute of Electrodynamics National Academy of Sciences of Ukraine, 2013. - 550 p. (Rus)

12. Shuvalov M.Yu., Obraztsov Yu.V., Ovsienko V.L., Udovitskij P.Yu., Mneka A.S. Growth of water trees in extruded cable insulation as Rebinder effect. Part 1 // Kabeli i Provoda. - 2006. - No 4 (299). - Pp. 14-19. (Rus)

13. Steennis E.F., Kreuger F.H. Water treeing in polyethylene cables // IEEE Trans. on Electrical Insulation. 1990. - Vol. 25. - Is. 5. - Pp. 989-1028.

14. Tanaka T., Fukuda T. Residual strain and water trees in XPLE and PE cables // Annual report of the Conference on Electrical insulation and Dielectric Phenomena. - Commission on Sociotechnical Systems, National Research Council, National Academy of Sciences. - Printing and Publishing Office, USA, Washington, 1975. - Pp. $239-249$.

15. Wang Z., Marcolongo P., Lemberg J.A., Panganiban B., Evans J.W., Ritchie R.O., Wright P.K. Mechanical fatigue as a mechanism of water tree propagation in TR-XLPE // IEEE Trans. on Dielectrics and Electrical Insulation. 2012. - Vol. 19. - No 1. - Pp. 321-330.

\section{УДК $621.315 .2: 004.94$}

\section{ЗВ'ЯЗАНІ ЕЛЕКТРИЧНІ ТА МЕХАНІЧНІ ПРОЦЕСИ В ПОЛІЕТИЛЕНОВІЙ ІЗОЛЯЦЇ̈ ЗА НАЯВНОСТІ ВОДНИХ ТРИЇНГІВ 3 ГІЛКАМИ СКЛАДНОЇ СТРУКТУРИ \\ Кучерява І.М., докт.техн.наук Інститут електродинаміки НАН України, пр. Перемоги, 56, Київ-57, 03680, Україна. \\ E-mail: rb.irinan@gmail.com}

Шляхом комп'ютерного моделювання досліджено розподіл електричного поля, електричної сили та механічних напружень у поліетиленовій ізолячії силового кабеля, яка містить окрему гілку водного триїнга. Розглянуто дві моделі гілки триїнга, щзо складається з низки сферичних мікровключень, з'єднаних ииліндричними каналами однакового радіуса та каналами, щяо зменшуються за товщиною. Показано, що дія електричної сили та розподіл електромеханічних напружень на кіниях більш тонких каналів триїнга сприяє їхньому руйнуванню і тим самим розвитку триїнгових структур у поліетиленовій ізоляції. Бібл. 15, рис. 5, табл. 1.

Ключові слова: поліетиленова ізоляція, мікророзмірні включення, канали водного триїнга, електричне поле, електромеханічні напруження, комп'ютерне моделювання.

\section{УДК $621.315 .2: 004.94$}

\section{СВЯЗАННЫЕ ЭЛЕКТРИЧЕСКИЕ И МЕХАНИЧЕСКИЕ ПРОЦЕССЫ В ПОЛИЭТИЛЕНОВОЙ ИЗОЛЯЦИИ ПРИ НАЛИЧИИ ВОДНЫХ ТРИИНГОВ С ВЕТВЯМИ СЛОЖНОЙ СТРУКТУРЫ \\ Кучерявая И.Н., докт.техн.наук} Институт электродинамики НАН Украины, пр. Победы, 56, Киев-57, 03680, Украина.

Путем компьютерного моделирования исследованы распределения электрического поля, электрической силь и механических напряжений в полиэтиленовой изолячии силового кабеля, содержащей отдельную ветвь водного триинга. Рассмотрены две модели ветви триинга, состоящей из цеепочки сферических микровключений, которые соединены ичилиндрическими каналами одинакового радиуса и каналами, уменьшающимися по толщине. Показано, что действие электрической силь и распределение электромеханических напряжений на кониах более тонких каналов триинга способствует их разрушению и тем самым развитию триинговых структур в полиэтиленовой изоляиии. Библ. 15 , рис. 5 , табл. 1.

Ключевые слова: полиэтиленовая изоляция, микроразмерные включения, каналы водного триинга, электрическое поле, электромеханические напряжения, компьютерное моделирование. 